\title{
RESEARCH
}

Open Access

\section{Joint hypermobility in children with idiopathic scoliosis: SOSORT award 2011 winner}

\author{
Dariusz Czaprowski ${ }^{*}$, Tomasz Kotwicki², Paulina Pawłowska ${ }^{1}$ and Lukasz Stoliński ${ }^{3}$
}

\begin{abstract}
Background: Generalized joint hypermobility (JHM) refers to increased joint mobility with simultaneous absence of any other systemic disease. JHM involves proprioception impairment, increased frequency of pain within joints and tendency to injure soft tissues while performing physical activities. Children with idiopathic scoliosis (IS) often undergo intensive physiotherapy requiring good physical capacities. Further, some physiotherapy methods apply techniques that increase joint mobility and thus may be contraindicated.

The aim of this paper was to assess JHM prevalence in children with idiopathic scoliosis and to analyze the relationship between JHM prevalence and the clinical and radiological parameters of scoliosis. The methods of assessment of generalized joint hypermobility were also described.

Materials and methods: This case-control study included 70 subjects with IS, aged 9-18 years (mean $13.2 \pm 2.2$ ), Cobb angle range $10^{\circ}-53^{\circ}$ (mean $24.3 \pm 11.7$ ), 34 presenting single curve thoracic scoliosis and 36 double curve thoracic and lumbar scoliosis. The control group included 58 children and adolescents aged 9-18 years (mean 12.6 \pm 2.1 ) selected at random. The presence of JHM was determined using Beighton scale complemented with the questionnaire by Hakim and Grahame. The relationship between JHM and the following variables was evaluated: curve severity, axial rotation of the apical vertebra, number of curvatures (single versus double), number of vertebrae within the curvature (long versus short curves), treatment type (physiotherapy versus bracing) and age. Statistical analysis was performed with Statistica 8.1 (StatSoft, USA). The Kolmogorov-Smirnov test, U Mann-Whitney test, $\mathrm{Chi}^{2}$ test, Pearson and Spermann correlation rank were conducted. The value $p=0.05$ was adopted as the level of significance.
\end{abstract}

Results: JHM was diagnosed in more than half of the subjects with idiopathic scoliosis (51.4\%), whilst in the control group it was diagnosed in only $19 \%$ of cases $(p=0.00015)$. A significantly higher JHM prevalence was observed in both girls $(p=0.0054)$ and boys $(p=0.017)$ with IS in comparison with the corresponding controls. No significant relation was found between JHM prevalence and scoliosis angular value ( $p=0.35)$, apical vertebra rotation ( $p=0.86)$, the number of vertebrae within curvature $(p=0.8)$, the type of applied treatment $(p=0.55)$ and the age of subjects $(p=0.79)$. JHM prevalence was found to be higher in children with single curve scoliosis than in children with double curve scoliosis $(p=0.03)$.

Conclusions: JHM occurs more frequently in children with IS than in healthy sex and age matched controls. No relation of JHM with radiological parameters, treatment type and age was found. Systematically searched in IS children, JHM should be taken into account when physiotherapy is planned.

Keywords: assessment of joint hypermobility, joint laxity, idiopathic scoliosis, Beighton scale

\footnotetext{
* Correspondence: dariusz.czaprowski@interia.pl

${ }^{1}$ Faculty of Physiotherapy, Józef Rusiecki University College in Olsztyn, 10-243

Olsztyn, Bydgoska 33, Poland

Full list of author information is available at the end of the article
} 


\section{Background}

Generalized joint hypermobility (JHM) is diagnosed when the mobility of small and large joints is increased in relation to standard mobility for any given age, gender and race, and after excluding systemic diseases [1].

The data concerning prevalence of JHM among children and adolescents varies significantly, ranging from 7 to $65 \%$ [2-6]. This discrepancy seems to depend on methodological differences - the threshold values in screening tests, gender and age of subjects. The majority of authors noted the co-occurrence of JHM with the following symptoms: back pain, anterior knee pain (femoro-patellar joint pain), foot pain, flat or plano-valgus foot as well as with disturbance of posture, particularly scoliotic posture and sway back posture [2,3,7-9]. Extreme positioning of joints, very typical of JHM patients, is commonly used by children in order to enhance postural stability. Moreover, children and adolescents with JHM can suffer from shortening of breath, decreased respiratory thorax expansion and more frequent mitral valve prolapse $[4,10,11]$. Proprioception is also disturbed, resulting in problems with accurately determining angular joint location $[12,13]$. The clinical consequence of generalized joint laxity may lead to repetitive joint injuries and consequently, to joint instability, subluxation and dislocation [4].

Idiopathic scoliosis (IS) is a multiplanar spine deformation, occurring in $0.5-3.0 \%$ of adolescents [14]. In accordance with guidelines provided by SOSORT for cases of mild and moderate scoliosis, conservative treatment is recommended [15]. This consist of corrective bracing and physiotherapy. Some methods of physiotherapy used to treat scoliotic children, include exercises that aim at increasing the range of spinal mobility to achieve curve correction [16-19]. It may be supposed that these exercises result in increased spinal mobility. Moreover, some therapeutic systems rely on proprioception to increase patient's ability to a sense of joint position $[16,20,21]$. There is a dearth of indepth reports on JHM prevalence in children with idiopathic scoliosis.

The aim of this study was to assess joint hypermobility occurrence in children with idiopathic scoliosis and to analyze the relationship between the JHM and the clinical and radiological parameters of scoliosis.

\section{Materials and methods Subjects}

The case-control study included 70 subjects aged 9-18 years (mean $13.2 \pm 2.2$ ) with idiopathic scoliosis. The criteria for inclusion to the study group were the following: diagnosis of idiopathic scoliosis on antero-posterior radiogram in accordance with SRS criteria (Cobb angle $>10^{\circ}$ with rotation), age range 9-18 years, absence of systemic diseases related to JHM (Ehlers-Danlos, Down, Marfan, Larsen) and participation consent. The control group consisted of 58 subjects (mean age $12.6 \pm 2.1$ years) randomly chosen according to the inclusion criteria: age range 9-18 years, less than $5^{\circ}$ of angle of trunk rotation as measured with Bunnell scoliometer, absence of systemic diseases and participation consent. Approval of the local ethical committee was obtained. The basic data for both groups is presented in Table 1 .

Additionally, the comparability between the study group and the control group was checked separately for the girls $(n=92)$ and boys $(n=36)$. The girls from the study group were significantly taller than the girls from the control group $(p=0.02)$, however, the groups were comparable in respect to age $(p=0.06)$, weight $(p=0.2)$ and BMI $(p=0.4)$. Boys from the study group were comparable to boys from the control group in respect to age $(p=0.1)$, height $(p=0.1)$, weight $(p=0.3)$ and BMI $(p=0.8)$.

Within the study group, the Cobb angle range was $10^{\circ}$ to $53^{\circ}$. In 34 cases, a single-curve thoracic scoliosis was present, while in the remaining 36 cases - a doublecurve thoracic and lumbar scoliosis. The average number of vertebrae forming single-curve scoliosis was 6.5 vertebrae (range 4-10). The value of apical vertebra rotation (AVR) was determined using the Cobb method [22]. 47 subjects were treated exclusively with physiotherapy, while the remaining 23 subjects received both physiotherapy and treatment with Cheneau brace.

\section{Instrumentation}

A nine-degree Beighton scale was used to determine the occurrence of generalized joint hypermobility [23] (Figure 1, 2, 3, 4, 5). In order to assess the range of joint mobility, a set of goniometers was used (Baseline, USA).

Additionally, a five-part questionnaire by Hakim and Graham was used [24] (Table 2). Obtaining 4 or more points on Beighton scale and simultaneously at least 2 points in the ques-tionnaire by Hakim and Graham was adopted as a criterion for JHM diagnosis.

The frequency of occurrence of the JHM was compared between the study and control groups. The same analysis was also performed separately for girls and

Table 1 Parameters of the study and the control group

\begin{tabular}{lccc}
\hline & $\begin{array}{c}\text { Study group } \\
\mathbf{n}=\mathbf{7 0} \\
\text { average (SD) }\end{array}$ & $\begin{array}{c}\text { Control group } \\
\mathbf{n}=\mathbf{5 8} \\
\text { average (SD) }\end{array}$ & $\boldsymbol{p}$ \\
\hline Age (years) & $13.2(2.2)$ & $12.6(2.1)$ & 0.08 \\
Height $(\mathrm{m})$ & $1.59(0.1)$ & $1.56(0.1)$ & 0.2 \\
Weight $(\mathrm{kg})$ & $49.5(13.0)$ & $47.4(14.8)$ & 0.7 \\
BMl $\left(\mathrm{kgm}^{-2}\right)$ & $19.2(3.4)$ & $18.8(3.5)$ & 0.99 \\
Cobb $\left(^{\circ}\right)$ & $24.3(11.7)$ & - & - \\
\hline
\end{tabular}




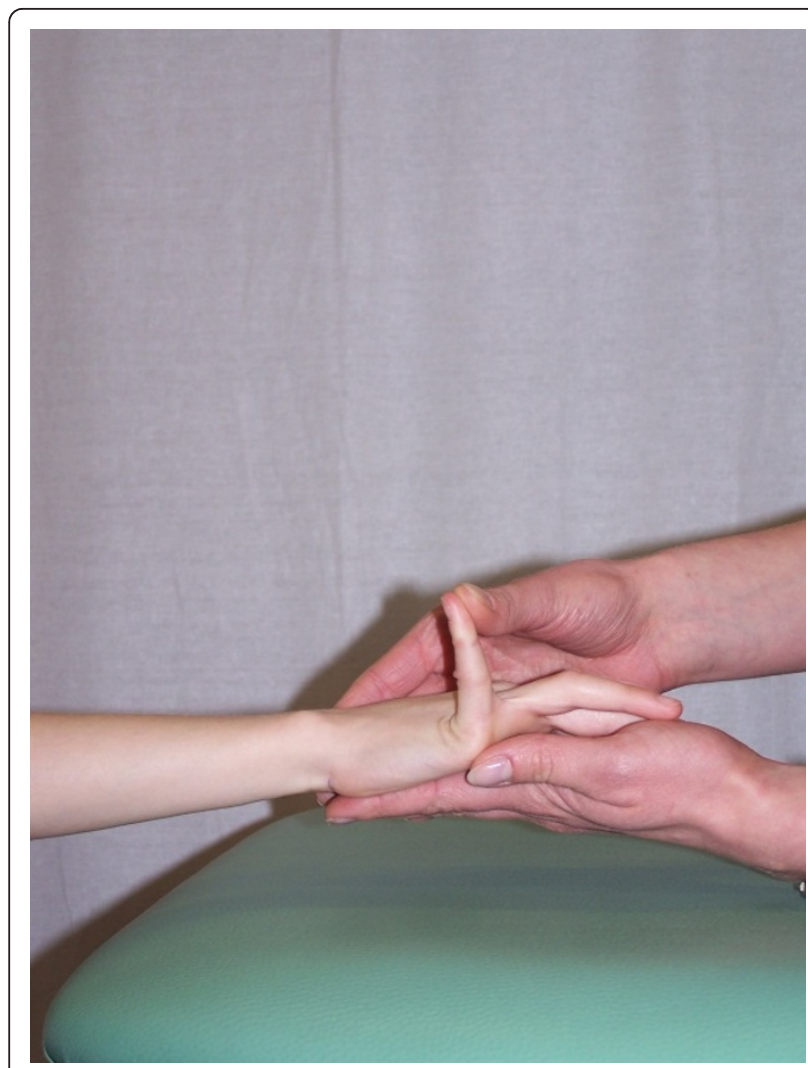

Figure 1 Extension of the MCP joint of the fifth finger

boys. JHM occurrence was compared between mild $\left(\right.$ Cobb $\left.10^{\circ}-24^{\circ}\right)$, moderate or severe $\left(\mathrm{Cobb} \geq 25^{\circ}\right)$ idiopathic scoliosis. Correlation between the Cobb angle and the number of points on the Beighton scale was checked. The relation of JHM occurrence to the following parameters was tested: (1) the apical vertebra rotation quantified according to Cobb as + versus ++ versus +++ , (2) number of curvatures - single versus double, (3) number

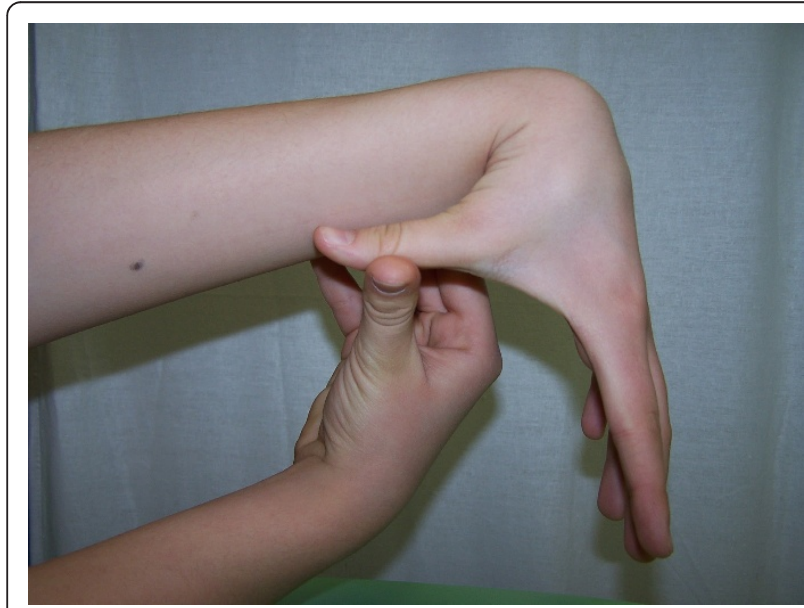

Figure 2 Abduction of the thumb to the forearm

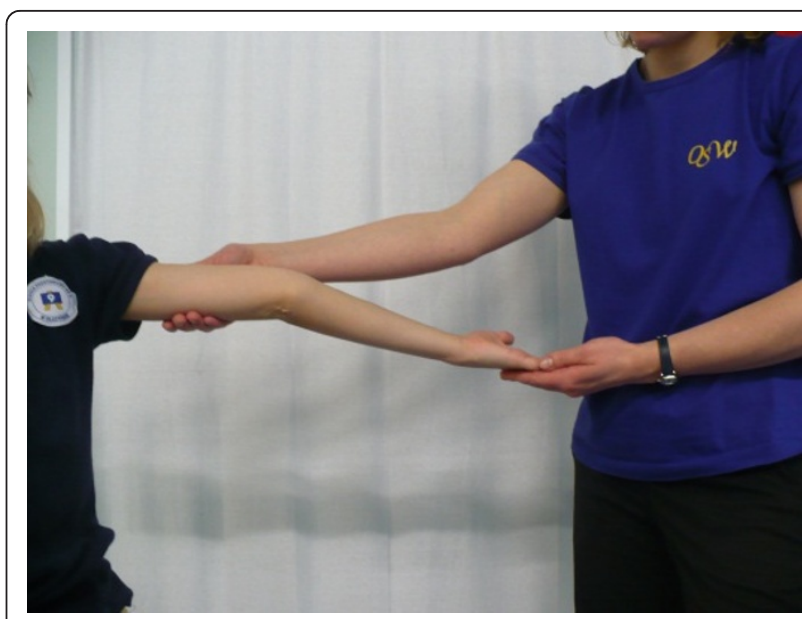

Figure 3 Elbow hyperextension.

of vertebrae within the single scoliosis curvature: above versus below the mean of 6.5 vertebrae, (4) type of management: physiotherapy alone versus physiotherapy and corrective bracing, (5) the age of patient: above or below the mean of 13.2 years. Correlation between the number of points in Beighton scale and age as well as between Beighton scale and the number of vertebrae included in the primary curvature was calculated.

Statistical analysis was performed with Statistica 8.1 (StatSoft, USA). The Kolmogorov-Smirnov test was initially applied to check normal distribution. The U MannWhitney test, $\mathrm{Chi}^{2}$ test, Pearson and Spermann correlation rank were also conducted to. The value $p=0.05$ was adopted as the level of significance.

\section{Results}

JHM was diagnosed in more than half the children with idiopathic scoliosis (51.4\%), whilst in the control group,

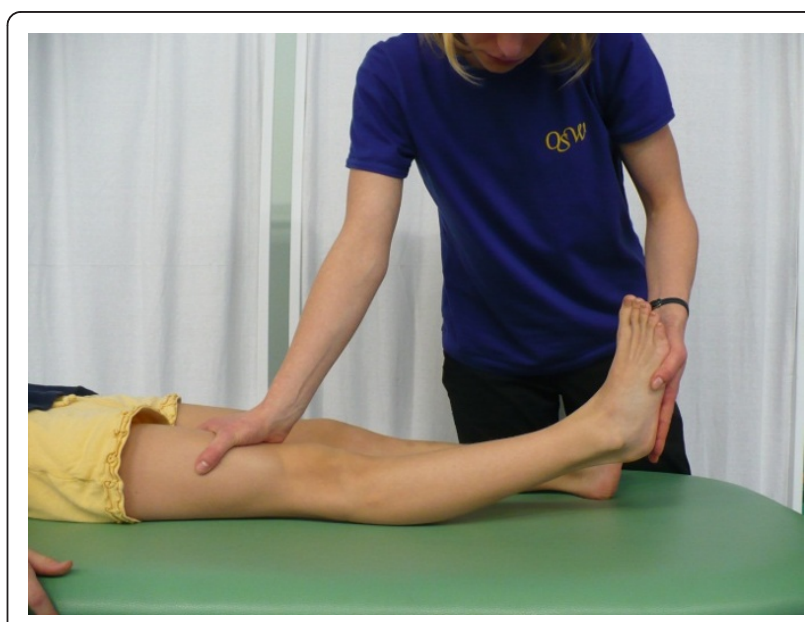

Figure 4 Knee hyperextension 


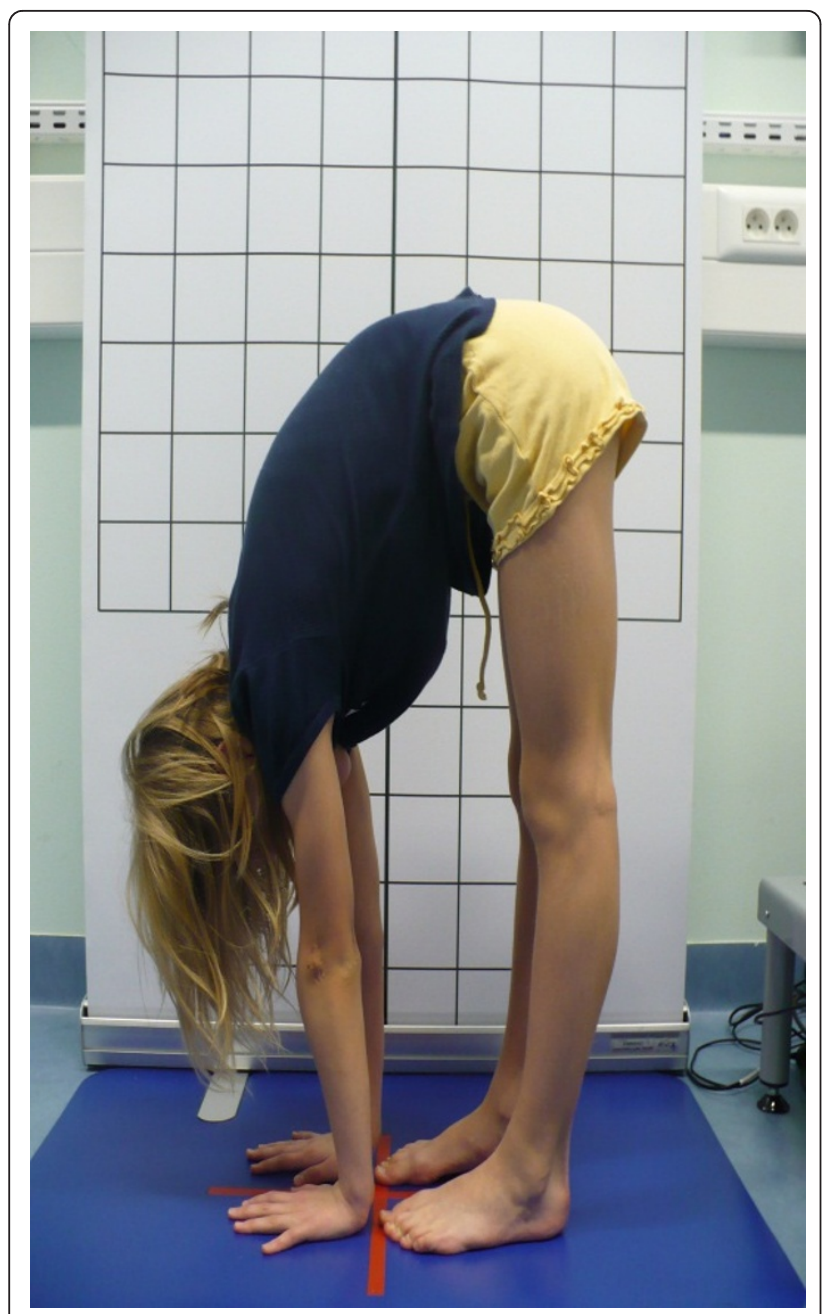

Figure 5 Touching the floor with the palms of the hands

it was diagnosed only in $19.0 \%$ of cases $(p=0.00015)$ (Table 3).

Both in the group of girls (Table 4) and boys (Table 5) with IS, significantly higher frequency of JHM was observed in comparison with the corresponding control groups.

JHM occurred in $56.1 \%$ children with mild scoliosis (10-24 $\mathrm{Cobb})$. In children with scoliosis of $25^{\circ}$ and above, the percentage of JHM was $44.8 \%$, difference not significant, $p=0.35$ (Table 6). The calculation of correlation between the angular value of curvature (Cobb
Table 3 Prevalence of joint hypermobility (JHM) in the study and the control group

\begin{tabular}{ccc}
\hline & $\begin{array}{c}\text { Study group } \\
\mathbf{n = 7 0}(\mathbf{1 0 0 . 0 \% )})\end{array}$ & $\begin{array}{c}\text { Control group } \\
\mathbf{n = 5 8}(\mathbf{1 0 0 . 0 \% )}\end{array}$ \\
\hline JHM present $-\mathrm{n}(\%)$ & $36(51.4)$ & $11(19.0)$ \\
JHM absent $-\mathrm{n}(\%)$ & $34(48.6)$ & $47(81.0)$ \\
\hline$p$ value & \multicolumn{3}{c}{$\mathbf{0 . 0 0 0 1 5}$} \\
\hline
\end{tabular}

degrees) and the number of points in Beighton scale failed to show any significant correlation $(R=-0.099 ; p$ $=0.4$ ).

No relation between the apical vertebra axial rotation and JHM frequency was found $(p=0.86)$ (Table 7).

Joint hypermobility occurred in $64.7 \%$ children with single-curve scoliosis, whilst in children with doublecurve scoliosis, the percentage was below 39\% which was significantly different $(\boldsymbol{p}=\mathbf{0 . 0 3})$ (Table 8 ).

No statistical relationship was observed between JHM prevalence and the length of single-curve scoliosis. Comparison of JHM percentage in children with the length of scoliosis below and above the accepted average proved to be statistically insignificant $(p=0.8)$ (Table 9 ), as did the correlation between the number of vertebra included in scoliotic deformation and the number of points obtained on Beighton scale $(R=-0.043, p=0.8)$.

Joint hypermobility was observed in $56.5 \%$ of children treated by both physiotherapy and Cheneau brace in comparison to $48.9 \%$ of children treated only by physiotherapy, difference not significant $(p=0.55)$ (Table 10).

Although the literature data shows decreasing JHM prevalence with age [21], this study did not show significant differences in the frequency of JHM occurrence in children with scoliosis aged 13.2 years or younger versus children aged over $13.2(p=0.79)$ (Table 11). However, the number of points on Beighton scale tended to decrease with age $(R=-0.268 ; \boldsymbol{p}=\mathbf{0 . 0 2})$.

\section{Discussion}

JHM is not considered to be a specific disease, but rather a phenomenon concerning the musculo-skeletal system of an individual subject [4]. The borderline between constitutional generalized joint hypermobility versus pathological skin and joint laxity (connective tissue disorders) is not always easily defined. In the

Table 2 A five-part questionnaire for identifying joint hypermobility [24]

\begin{tabular}{l}
$\frac{1 . \text { Can you now (or could you ever) place your hands flat on the floor without bending your knees? }}{\text { 2. Can you now (or could you ever) bend your thumb to touch your forearm? }}$ \\
\hline 3. As a child did you amuse your friends by contorting your body into strange shapes or could you do the splits? \\
\hline 5. Do you consider yourself double-jointed? \\
\hline
\end{tabular}


Table 4 Difference in prevalence of joint hypermobility (JHM) between girls from the study and from the control group

\begin{tabular}{ccc}
\hline & $\begin{array}{c}\text { Study group - girls } \\
\mathbf{n = 5 9 ( 1 0 0 . 0 \% )}\end{array}$ & $\begin{array}{c}\text { Control group - girls } \\
\mathbf{n = 3 3}(\mathbf{1 0 0 . 0 \% )}\end{array}$ \\
\hline JHM present $-\mathrm{n}(\%)$ & $30(50.8)$ & $7(21.0)$ \\
JHM absent $-\mathrm{n}(\%)$ & $29(49.2)$ & $26(79.0)$ \\
\hline$p$ value & \multicolumn{3}{c}{$\mathbf{0 . 0 0 5 4}$} \\
\hline
\end{tabular}

classification of children's diseases adopted by pediatricians, patients with generalized joint hypermobility are reported to have a Benign Joint Hypermobility Syndrome (BJHS) $[1,25]$. The term was introduced to emphasize the differences between BJHS and HDCT Hereditary Disorders of Connective Tissue [25]. The latter, which pertains to innate disorders in the connective tissue, is exemplified by Marfan syndrome, Larsen syndrome, Ehlers-Danlos syndrome or osteogenesis imperfecta $[1,26,27]$. These diseases represent well described clinical entities, however, differential diagnosis of some border conditions, for example of benign forms of Ehlers-Danlos syndrome, would require genetic examination. Nevertheless, in screening and in everyday practice, the clinical examination remains the means to assess both benign constitutional joint hypermobility and pathological soft tissue laxity. It is important to remember that the latter is expressed within the skin; the assessment of the skin fold and skin laxity being an important part of the examination.

This study showed that JHM occurs more frequently in patients with IS, in comparison with healthy controls. This regularity applies to both girls and boys. No relation between the frequency of JHM occurrence and the angular value of scoliotic curvature, apical vertebra rotation, length of scoliosis or applied conservative treatment was observed. No correlation between the number of Beighton scale points and the angular value of curvature was found. This study suggests that even if children with IS are more prone to present joint hypermobility, this is not associated with radiological parameters of scoliosis. JHM rate was significantly higher in the group of children with single curve scoliosis in comparison to children with double curve scoliosis $(p=0.03)$. This finding requires further studies, to exclude whether it

Table 5 Difference in prevalence of joint hypermobility (JHM) between boys from the study and from the control group

\begin{tabular}{ccc}
\hline & $\begin{array}{c}\text { Study group - boys } \\
\mathbf{n}=\mathbf{1 1}(\mathbf{1 0 0 . 0 \% )}\end{array}$ & $\begin{array}{c}\text { Control group - boys } \\
\mathbf{n = 2 5}(\mathbf{1 0 0 . 0 \% )}\end{array}$ \\
\hline JHM present $-\mathrm{n}(\%)$ & $6(54.5)$ & $4(16.0)$ \\
$\mathrm{JHM}$ absent $-\mathrm{n}(\%)$ & $5(45.5)$ & $21(84.0)$ \\
\hline$p$ value & & $\mathbf{0 . 0 1 7}$
\end{tabular}

Table 6 Prevalence of joint hypermobility (JHM) in relation to curve angle

\begin{tabular}{ccc}
\hline & $\begin{array}{c}\text { Cobb } \mathbf{1 0}^{\circ}-\mathbf{2 4} \\
\mathbf{n = 4 1}(\mathbf{1 0 0 . 0 \% )}\end{array}$ & $\begin{array}{c}\text { Cobb } \geq \mathbf{2 5} \\
\mathbf{n}=\mathbf{2 9}(\mathbf{1 0 0 . 0 \% )}\end{array}$ \\
\hline JHM present $-\mathrm{n}(\%)$ & $23(56.1)$ & $13(44.8)$ \\
JHM absent $-\mathrm{n}(\%)$ & $18(43.9)$ & $16(55.2)$ \\
\hline$p$ value & & 0.35 \\
\hline
\end{tabular}

represented just a statistical phenomenon; it seems unjustified to speculate on cause-result relation at this point.

Joint mobility range decreases with age. It is at its highest point just after birth, after which it gradually decreases, most rapidly in the childhood period $[4,5,7,23,25]$. This natural tendency for JHM frequency to diminish with age was not confirmed by our study, as JHM did not differ significantly in children aged below versus those aged above the average of 13.2 years $(p=$ 0.79 ). However, in children with IS, the number of Beighton scale points tended to decrease with age ( $p=$ 0.02). The results indicate that while JHM frequency does not decrease with age of children with IS, the intensity of clinical signs seems to diminish.

Methods of assessment of generalized joint hypermobility Different authors apply various names to define increased joint mobility, despite using similar diagnostic scales. The following exemplifies this variety: Joint hypermobility (JHM), Joint hypermobility syndrome JHS, Benign hypermobility syndrome (BHS), Benign joint hypermobility syndrome (BJHS) or Joint laxity [2-8,12,25-31]. This lack of consistency is an obstacle to direct comparison of results [4]. Gedalia et al., with the use of Beighton scale, reported that JHM occurs in 12\% of American pupils aged 5-17, where in 18\% of girls and in $7 \%$ of boys [2]. The study by Vougiouka et al. assessing right limbs and lumbar spine flexion proved that Benign Hypermobility Syndrome occurs in $8.78 \%$ of children aged 5-14 [3]. The authors emphasize that BHS occurs in a significantly smaller percentage of boys than girls (7.1\% versus $10.7 \%)$. Hakim and Grahame analyzed

Table 7 Prevalence of joint hypermobility (JHM) in subjects with apical vertebra axial rotation (AVR) quantified according to Cobb method as: AVR +, AVR ++ or AVR +++

\begin{tabular}{cccc}
\hline & $\begin{array}{c}\text { AVR }+ \\
\mathbf{n = 3 0} \\
(\mathbf{1 0 0 . 0 \% )}\end{array}$ & $\begin{array}{c}\text { AVR }++ \\
\mathbf{n = 2 2} \\
(\mathbf{1 0 0 . 0 \% )}\end{array}$ & $\begin{array}{c}\text { AVR +++ } \\
\mathbf{n = 1 8} \\
(\mathbf{1 0 0 . 0 \% )}\end{array}$ \\
\hline $\begin{array}{c}\text { JHM } \\
\text { present }-\mathrm{n}(\%)\end{array}$ & $14(46.7)$ & $12(54.5)$ & $8(44.4)$ \\
JHM absent $-\mathrm{n}(\%)$ & $16(53.3)$ & $10(45.5)$ & $10(55.6)$ \\
\hline$p$ value & & 0.86 & \\
\hline
\end{tabular}


Table 8 Determining the level of diversity in joint hypermobility (JHM) prevalence in subjects with singlecurve versus double-curve scoliosis

\begin{tabular}{ccc}
\hline & $\begin{array}{c}\text { Single-curve } \\
\mathbf{n = 3 4}(\mathbf{1 0 0 . 0 \% )})\end{array}$ & $\begin{array}{c}\text { Double-curve } \\
\mathbf{n = 3 6}(\mathbf{1 0 0 . 0 \% )}\end{array}$ \\
\hline JHM present $-\mathrm{n}(\%)$ & $22(64.7)$ & $14(38.9)$ \\
JHM absent $-\mathrm{n}(\%)$ & $12(35.3)$ & $22(61.1)$ \\
\hline$p$ value & & $\mathbf{0 . 0 3}$ \\
\hline
\end{tabular}

the results of 7 examinations conducted on children aged 11-17 [4]. Their analysis shows that JHM occurs in approximately $10-15 \%$ of boys and $20-40 \%$ of girls. Observations made with the use of Beighton scale in Brazilian children aged 4-7 indicated that as many as $64.6 \%$ of children in that group presented JHM [5]. Similar figures were obtained by de Inocencio Arocena et al. (Beighton scale), who confirmed JHM occurrence in $55 \%$ of children aged 4-14 [6]. It seems that important differences between publications result basically from the diverse methodologies used.

\section{Beighton scale}

The most frequent method used in clinical screening is Beighton 9-point scale $[4,23,32,33]$. It consists of exclusively assessing joint mobility: extension of the fifth MPC joint to $90^{\circ}$, thumb abduction to front forearm, hyperextension of elbow joint above $10^{\circ}$, hyperextension of knee joint above $10^{\circ}$ as well as capability to stand bend and place one's palms flat on the ground. Each hypermobile joint gets one point. To diagnose JHM, at least 4 points have to be obtained $[4,23,34]$.

\section{Carter and Wilkinson method}

Carter and Wilkinson published a method of assessment of generalized joint hypermobility about a decade before Beighton score was introduced [29-31]. Their scale takes into account similar articulations: the thumb, elbow and knee joints. The first difference from Beighton scale concerns the assessment of passive hyperextension of all four II-V fingers to a position parallel to the forearm extensor aspect (Figure 6), instead of the assessment of the fifth finger only. The second difference involves assessing the range of ankle dorsiflexion beyond $45^{\circ}$ in the Carter and Wilkinson's method (Figure 7), instead of assessing the ability to touch the ground with one's

Table 9 Determining the level of differences in JHM prevalence in subjects with scoliosis length below $(<6$

\begin{tabular}{ccc}
\hline & $\begin{array}{c}\text { Group }<6.5 \\
\mathbf{n}=\mathbf{1 8}(\mathbf{1 0 0 . 0 \% )})\end{array}$ & $\begin{array}{c}\text { Group }>\mathbf{6 . 5} \\
\mathbf{n}=\mathbf{1 6}(\mathbf{1 0 0 . 0 \% )}\end{array}$ \\
\hline JHM present $\mathrm{n}(\%)$ & $12(66.7)$ & $10(62.5)$ \\
\hline JHM absent $(\%)$ & $6(33.3)$ & $6(37.5)$ \\
\hline$p$ value & & 0.8 \\
\hline
\end{tabular}

Table 10 Assessment of joint hypermobility (JHM) prevalence in the group of subjects treated only with physiotherapy versus treated with physiotherapy and Cheneau brace

\begin{tabular}{ccc}
\hline & $\begin{array}{c}\text { Physiotherapy } \\
\mathbf{n = 4 7 ( 1 0 0 . 0 \% )}\end{array}$ & $\begin{array}{c}\text { Physiotherapy and bracing } \\
\mathbf{n = 2 3}(\mathbf{1 0 0 . 0 \% )}\end{array}$ \\
\hline JHM present $-\mathrm{n}(\%)$ & $23(48.9)$ & $13(56.5)$ \\
$\mathrm{JHM}$ absent $-\mathrm{n}(\%)$ & $24(51.1)$ & $10(43.5)$ \\
\hline$p$ value & & 0.55 \\
\hline
\end{tabular}

palms as adopted by Beighton. Both scales are considered to be reliable in the assessment of joint hypermobility [30]. It is also important to notice that ankle dorsiflexion beyond $45^{\circ}$ may be limited even in hypermobile subjects by relative shortening of the triceps muscle which is quite a common condition in a growing population. On the other hand, touching the floor with one's hands, as proposed by Beighton, can be executed by subjects who are not hypermobile but who have experienced intensive stretching of the hamstring muscles.

\section{Marshall test}

Marshall test is another method of assessing joint hypermobility based on the thumb motion range measured in the forearm direction [35]. The following figures show scores obtained during this test: I $-<45^{\circ}$ of passive thumb abduction (Figure 8); II $-45^{\circ}$ of abduction (Figure 9); III $-90^{\circ}$ of abduction (Figure 10); IV - $135^{\circ}$ of abduction (Figure 11), and V - thumb can be opposed to the forearm (Figure 12). Marshall test is widely used for its simplicity. The disadvantage of this test is the fact that it focuses only on one joint.

\section{Bulbena scale}

Bulbena scale is a 10-point scale used to assess generalized joint hypermobility [36]. It takes into consideration the signs in upper extremities, lower extremities and skin. The above described methods are summarized in Table 12.

\section{Threshold to diagnose JHM}

Apart from various methods used to assess generalized joint hypermobility, within a given method, different

Table 11 Comparison of joint hypermobility (JHM) prevalence in group of subjects with scoliosis aged below versus above the average of 13

\begin{tabular}{ccc}
\hline & $\begin{array}{c}<\mathbf{1 3 . 2} \\
\mathbf{n}=\mathbf{3 2}(\mathbf{1 0 0 . 0 \% )}\end{array}$ & $\mathbf{n = 3 8}(\mathbf{1 0 0 . 0} \%)$ \\
\hline JHM present $-\mathrm{n}(\%)$ & $17(53.1)$ & $19(50.0)$ \\
JHM absent $-\mathrm{n}(\%)$ & $15(46.9)$ & $19(50.0)$ \\
\hline$p$ value & 0.79 \\
\hline
\end{tabular}




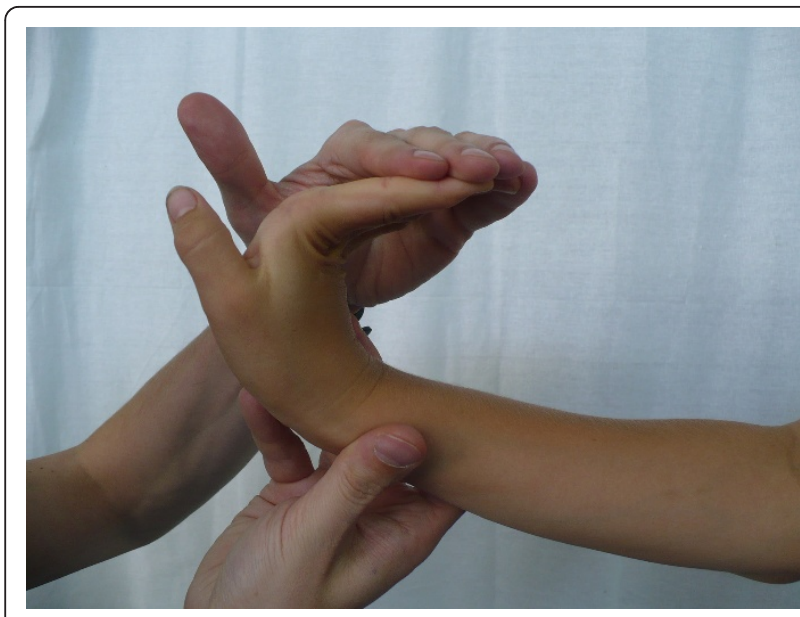

Figure 6 Passive hyperextension of all MCPs of the II-V fingers to a position parallel to the extensor aspect of the forearm.

cut-off values have been proposed. For the purposes of diagnosing JHM in children, Lamari et al. adopted 3 of the 9 points values from Beighton scale [5]. A similar threshold was adopted by Gedalia et al. [2]. According to Grahame and Bird $87 \%$ of British rheumatologists consider that at least 3 hypermobile joint suffice to diagnose JHM [37]. However, Smits-Engelsman et al. suggests that the minimal threshold value should be at least 7 points in the 9-point scale [32]. In 1998, criteria from Brighton were introduced to diagnose BJHS, comprising the so-called major and minor criteria. However, the Brighton scale requires specific examinations which are difficult in screening conditions, for example rectal prolapse or joint inflammation [4,28]. Hakim and Grahame as well as Hakim and Sahota suggest that the diagnosis of JHM should be supplemented with a 5-point questionnaire [24,34]. It would allow a fast clinical overview as its questions refer to symptoms observed both at

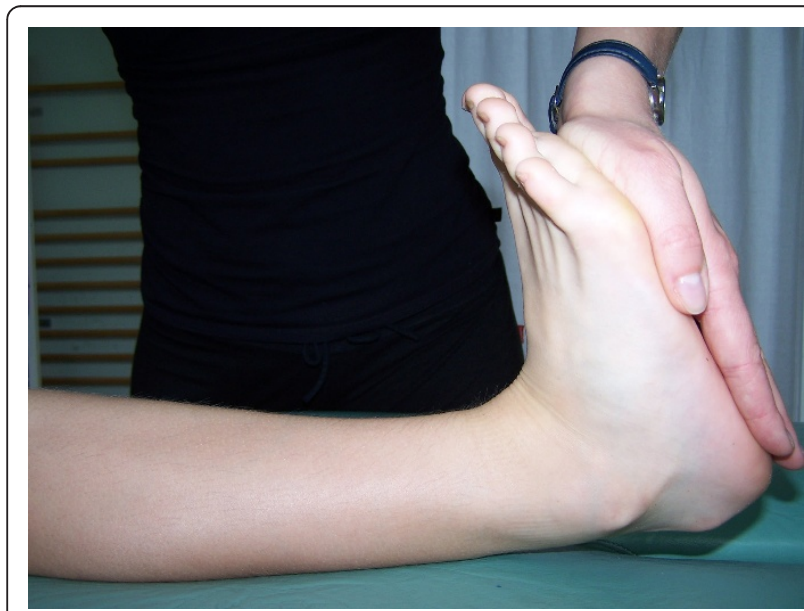

Figure 7 Ankle dorsiflexion.

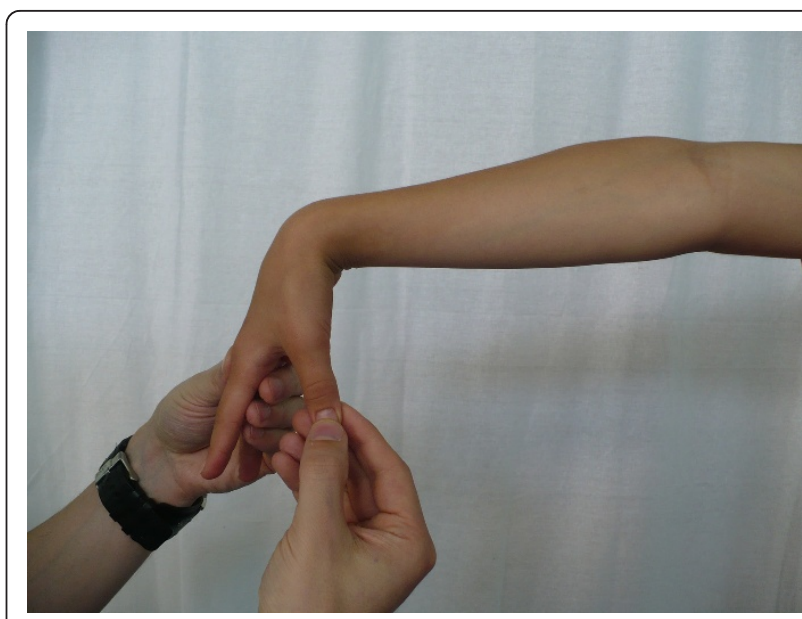

Figure $8 \mathrm{I}-<45^{\circ}$ of passive thumb abduction.

present and in the past, thus accounting for mobility changes that occur with age. A positive answer to two or more questions would indicate hypermobility with sensitivity of $80-85 \%$ and specificity of $80-90 \%[4,24,34]$.

The authors of this study used a 9-point Beighton scale to assess JHM prevalence with the threshold level of minimum 4 points, supplemented with a 5-part questionnaire to avoid false positive results, as suggested by Hakim and Grahame [23,24].

The studies determining the prevalence of JHM usually refer to healthy population of children and adolescents $[2,3,5,6,38,39]$. The second group of papers compares occurrence of accompanying symptoms and signs in children with JHM versus their prevalence in the control group $[4,7-9,40,41]$. The authors, however, are not aware of any reports on JHM prevalence in children suffering from idiopathic scoliosis. Binns found decreased thumb-to-forearm distance measured during

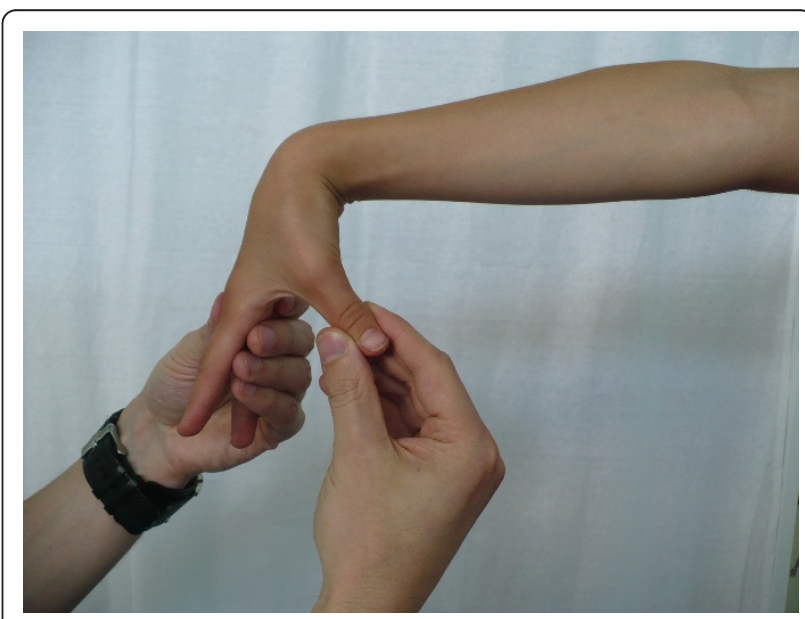

Figure 9 II $-45^{\circ}$ of thumb abduction. 


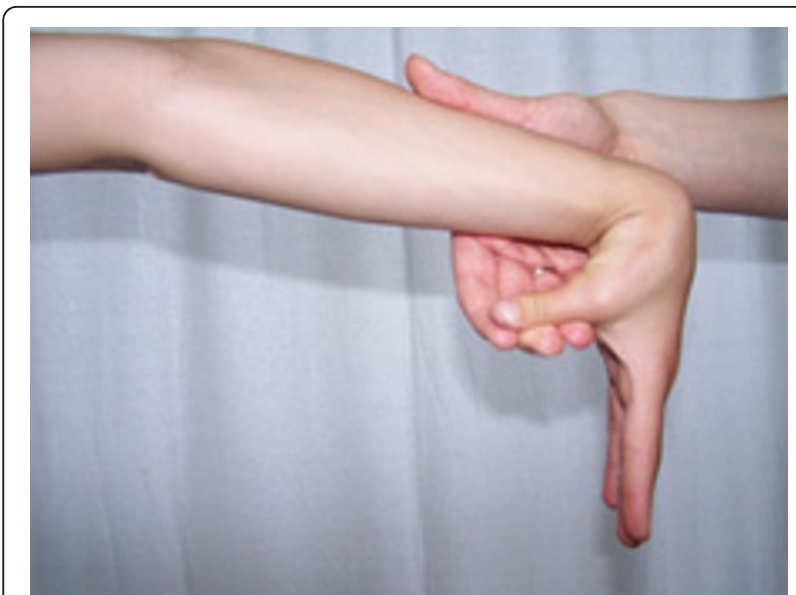

Figure $10 \mathrm{III}-90^{\circ}$ of thumb abduction.

passive apposition in Chinese patients with adolescent idi-opathic scoliosis [42]. This suggests that they are relatively hyperlax; however, the study was based solely on thumb mobility.

The issue of JHM in idiopathic scoliosis seems clinically important as these children may be subjected to intensive physiotherapy according to various approaches ("schools"). These therapeutic activities include, for

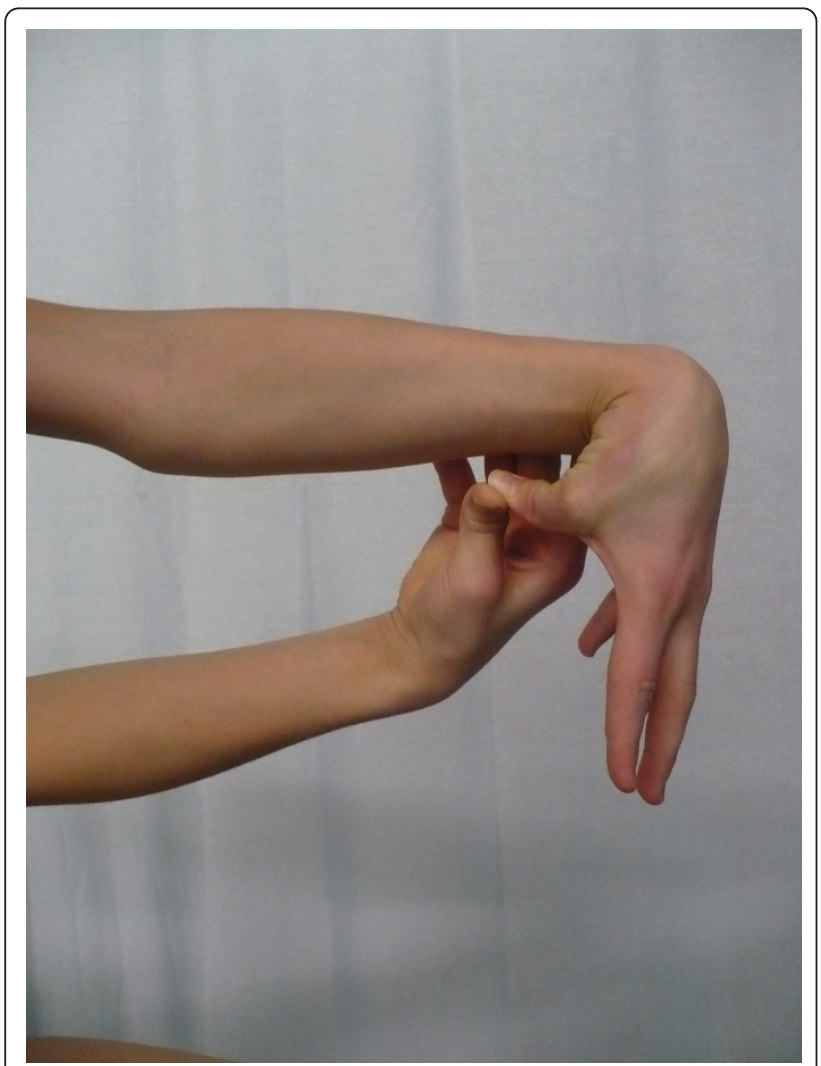

Figure $11 \mathrm{IV}-135^{\circ}$ of thumb abduction.

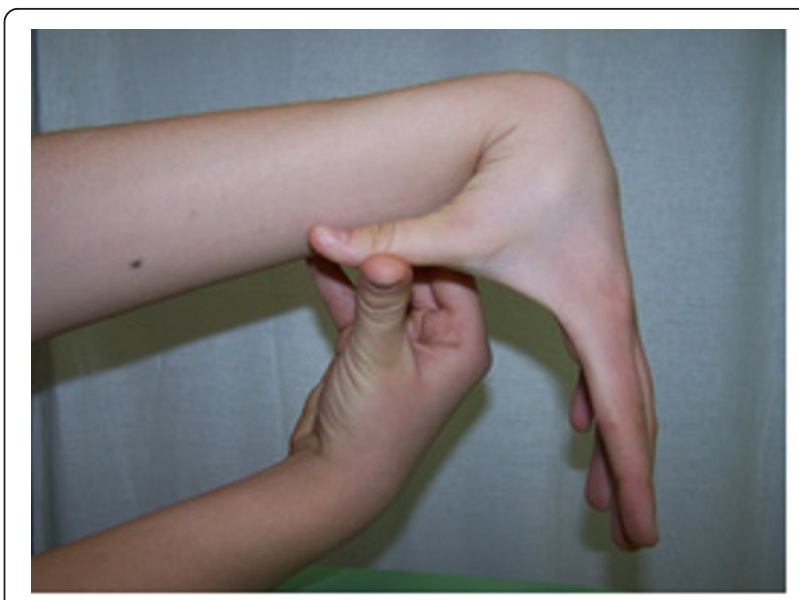

Figure $12 \mathrm{~V}$ - Thumb opposed to the forearm (as in the Beighton scale).

example, flexibility exercises, passive stretching exercises, as well as proprioception exercises [16-21,43]. Thus, it seems crucial to assess JHM prevalence in these patients. According to Keer and Grahame, physiotherapy is a mainstay of musculoskeletal aspects of JHS treatment [44]. However, those authors emphasize the fact that patients often complain about physiotherapy, claiming that their condition seems to have deteriorated, especially when their hypermobile joints are not handled with due care while treated manually. Moreover, physiotherapists often admit that their knowledge about JHM patients is not sufficient [44]. Such knowledge has great significance since it is typical of JHM patients to be particularly vulnerable to soft tissue injuries which occur during physical exercises. Additionally the increased sensitivity of pain receptors as well as recurrent micro injuries can increase the risk of joint injuries $[4,41]$.

The results indicate significantly higher JHM prevalence in children with idiopathic scoliosis, supported by the commonly recognized negative impact of this impairment on the locomotor system of children treated with physiotherapy. Assessing JHM needs to be taken into consideration when planning physiotherapy for IS children. This is even more true given the fact that JHM diagnosis is not time consuming and is based on screening tests that are easy to perform.

\section{Conclusions}

1. Joint hypermobility appears more often in children with idiopathic scoliosis than in healthy age and sex matched controls.

2. There was no relation of joint hypermobility prevalence with the Cobb angle value, Cobb apical vertebra axial rotation, length of scoliosis or treatment type. 
Table 12 Comparison of Beighton, Carter and Wilkinson, Bulbena and Marshall scales for diagnosis of joint hypermobility

\begin{tabular}{|c|c|c|c|c|}
\hline Criterion & $\begin{array}{l}\text { Beighton } \\
{[4,23,34]}\end{array}$ & $\begin{array}{l}\text { Carter and Wilkinson } \\
\text { [29] }\end{array}$ & $\begin{array}{l}\text { Bulbena } \\
\text { [36] }\end{array}$ & Marshall [35] \\
\hline Thumb abduction & $1^{a}$ & 1 & 1 & $\begin{array}{l}\text { Grade I } \\
\text { through V }\end{array}$ \\
\hline Elbow hyperextension $>10^{\circ}$ & $1^{\mathrm{a}}$ & 1 & 1 & \\
\hline Fifth finger extension $>90^{\circ}$ in MCP joint & $1^{a}$ & $\begin{array}{c}1 \\
\text { passive hyperextension of } \|-V \text { fingers parallel to } \\
\text { the forearm }\end{array}$ & 1 & \\
\hline Knee hyperextension $>10^{\circ}$ & $1^{\mathrm{a}}$ & 1 & & \\
\hline Foot dorsiflexion & & $\left(>45^{\circ}\right)$ & $\left(>20^{\circ}\right)$ & \\
\hline Palms flat on floor & 1 & & & \\
\hline Passive shoulder external rotation $>85^{\circ}$ & & & 1 & \\
\hline $\begin{array}{l}\text { Knee flexion allows the heel to make contact with } \\
\text { the buttocks }\end{array}$ & & & 1 & \\
\hline \multicolumn{5}{|l|}{$\begin{array}{l}\text { Passive shift of the patella to the lateral side of the } \\
\text { tibia }\end{array}$} \\
\hline Passive hip abduction $>85^{\circ}$ & & & 1 & \\
\hline $\begin{array}{l}\text { Hyperextension of MTP joints of the first finger }> \\
90^{\circ}\end{array}$ & & & 1 & \\
\hline $\begin{array}{l}\text { Appearance of ecchymoses after hardly noticed } \\
\text { minimal trauma }\end{array}$ & & & 1 & \\
\hline Total score & 9 & 5 & 10 & $\mathrm{H}-\mathrm{V}$ \\
\hline Number of point for diagnosis & $\begin{array}{l}4 \\
{[4,6,33,34]} \\
\quad 7[32]\end{array}$ & $3[29]$ & $\begin{array}{l}\text { female } \geq 5 \text {, male } \\
\quad \geq 4[36]\end{array}$ & \\
\hline
\end{tabular}

a 1 point per each side

3. Joint hypermobility should be systematically assessed in IS children and when found, taken into account when physiotherapy is planned.

\section{List of abbreviations}

JHM: Joint hypermobility; JHS: Joint hypermobility syndrome; BHS: Benign hypermobility syndrome; BJHS: Benign joint hypermobility syndrome; IS: Idiopathic scoliosis; AVR: Apical vertebral rotation; MCP: Metacarpophalangeal joint; MTP: Metatarsophalangeal joint

\section{Acknowledgements}

Written consent for publication was obtained from the patients or their relatives.

\section{Author details}

'Faculty of Physiotherapy, Józef Rusiecki University College in Olsztyn, 10-243 Olsztyn, Bydgoska 33, Poland. ${ }^{2}$ Department of Pediatric Orthopedics and Traumatology, University of Medical Sciences inPoznań, 61-545 Poznań, ul. 28 Czerwca nr 135, Poland. ${ }^{3}$ Rehasport Clinic, Poznań, Poland.

\section{Authors' contributions}

DC conceived the study, collected and interpreted the data and drafted the manuscript. TK participated in the design of the study, interpreted the data and drafted the manuscript. PP collected the data and helped to draft the manuscript. LS helped to the draft the manuscript. All the authors read and approved the final manuscript.

\section{Competing interests}

The authors declare that they have no competing interests.

Received: 5 July 2011 Accepted: 7 October 2011

Published: 7 October 2011

\section{References}

1. Sherry DD, Malleson P: Nonrheumatic Musculoskeletal Pain. In Textbook of Pediatric Rheumatology. Edited by: Cassidy JJT, Petty RE. Philadelphia: Saunders Comp; 2001:362-363.

2. Gedalia A, Person DA, Brewer EJ Jr, Gianini EH: Hypermobility of the joints in juvenile episodic arthritis/arthralgia. Journal of Pediatrics 1985, 107:873-876.

3. Vougiouka O, Moustaki M, Tsanaktsi M: Benign hypermobility syndrome in Greek schoolchildren. Eur J Ped 2000, 159(8):628.

4. Hakim A, Grahame R: Joint hypermobility. Best Practice \& Research Clinical Rheumatology 2003, 17(6):989-1004.

5. Lamari NM, Chueire AG, Cordeiro JA: Analysis of joint mobility patterns among preschool children. Sao Paolo Medical Journal 2005, 123(3):119-123.

6. De Inocencio AJ, Casas OI, Ortiz BL: Joint hypermobility: prevalence and relationship with musculoskeletal pain. Anales de Pediatria (Barc) 2004, 61:162-166.

7. Adib N, Davies K, Grahame R, Woo P, Murray K: Joint hypermobility syndrome in childhood. A not so benign multisystem disorder? Rheumatol 2005, 44:744-50.

8. Mikkelsson M, Salminen JJ, Kautiainen H: Joint hypermobility is not a contributing factor to musculoskeletal pain in pre-adolescents. Journal of Rheumatology 1996, 23(11):1963-1967.

9. Murray KJ: Hypermobility disorders in children and adolescents. Best Practice \& Research Clinical Rheumatology 2006, 20(2):329-351.

10. Grahame R, Edwards JC, Pitcher D, Gabell A, Harvey W: A clinical and echocardiographical study of patients with the hypermobility syndrome. Ann Rheum Dis 1981, 40:541-546.

11. Ondrasik M, Rybar I, Rus V, Bosak V: Joint hypermobility in primary mitral valve prolapse patient. Clin Rheumatol 1988, 7:69-73.

12. Hall MG, Ferrell WR, Sturrock RD, et al: The effect of the hypermobility syndrome on knee joint proprioception. British Journal of Rheumatology 1995, 34:121-125.

13. Mallik AK, Ferrell WR, McDonald AG, Sturrock RD: Impaired proprioceptive acuity at the proximal interphalangeal joint in the patients with the hypermobility syndrome. British Journal of Rheumatology 1994, 33:631-637. 
14. Parent S, Newton PO, Wenger D: Etiology, anatomy and natural history. In Adolescent idiopathic scoliosis. Edited by: Newton PO. Rosemont, IL: American Academy of Orthopaedic Surgeons; 2004:1-9.

15. Weiss HR, Negrini S, Hawes M, Rigo M, Kotwicki T, Grivas TB, Maruyama T: Physical exercises in the treatment of idiopathic scoliosis at risk of brace treatment- SOSORT consensus paper 2005. Scoliosis 2006, 1:6.

16. Białek M, M'Hango A: FITS Concept Functional Individual Therapy of Scoliosis. In The Conservative Scoliosis Treatment. Edited by: Grivas TB. Amsterdam: IOS Press; 2008:250-261.

17. Karski T, Kalakucki J, Karski J: "Syndrome of Contractures" (Acording to Mau) with the Abduction Contracture of the Right Hip as Causative Factor for Development of the So-Called Idiopathic Scoliosis. Studies in Health Technology and Informatics 2006, 123:34-39.

18. Bauknecht K: Scoliosis dance therapy: a worth-while addition to conservative scoliosis treatments? A pilot study evaluating the effect of a DVD led instruction on the wellbeing of scoliosis sufferers. 8th Annual Meeting of the SOSORT, International Conference on Conservative Management of Spinal Deformities, Barcelona 19-21.05.2011.

19. Sastre S, Lapuente JP, Santapau C, Bueno M: Dynamic Treatment of Scoliosis (The Results of 174 Cases). Research into Spinal Deformities Amsterdam: IOS Press; 1999.

20. Rigo M, Quera-Salva G, Villagrasa M, Ferrera M, Casas A, Corbella C, Urrutia A, Martinez S, Puigdevall N: Scoliosis Intensive Out-Patient Rehabilitation Based on Schroth Method. In The Conservative Scoliosis Treatment. Edited by: Grivas TB. Amsterdam: IOS Press; 2008:208-227.

21. Romano M, Negrini A, Parzini S, Negrini S: Scientific Exercises Approach to Scoliosis (SEAS): Efficacy, Efficiency and Innovation. In The Conservative Scoliosis Treatment. Edited by: Grivas TB. Amsterdam: IOS Press; 2008:191-207.

22. Lam GC, Hill DL, Lawrence HL, Raso VR, Lou EH: Vertebral rotation measurement: a summary and comparison of common radiographic and CT methods. Scoliosis 2008, 3:16.

23. Beighton P, Grahame R, Bird H: Hypermobility of joints. 3 edition. London: Springer; 1999

24. Hakim AJ, Grahame R: A simple questionnaire to detect hypermobility: an adjunct to the assessment of patients with diffuse musculoskeletal pain. International Journal of Clinical Practice 2003, 57:163-166.

25. Smolewska E, Brózik H, Stańczyk J: Hypermobility syndrome as a cause of arthralgia in children. Przeglą pediatryczny 2004, 34(1):13-16.

26. Baum J, Larsson L-G: Hypermobility Syndrome - new diagnostic criteria. J Rheumatol 2000, 27:1585-1586.

27. Kirk JH, Ansell B, Bywaters EGL: The hypermobility syndrome: musculoskeletal complaints associated with generalized joint hypermobility. Ann Rheum Dis 1967, 26:419-425.

28. Grahame R, Bird HA, Child A: The revised (Brighton 1998) criteria for the diagnosis of benign joint hypermobility syndrome (BJHS). Journal of Rheumatology 2000, 27:1777-1779.

29. Carter C, Wilkinson J: Persistent joint laxity and congenital dislocation of the hip. J Bone Joint Surg (Br) 1964, 46:40-5.

30. Cheng JCY, Chan PS, Hui PW: Joint laxity in children. Journal of Pediatric Orthopaedics 1991, 11:752-756.

31. Flynn JM, MacKenzie W, Kolstad K, Sandifer E, Jawad AF, Galinat B: Objective evaluation of knee laxity in children. Journal of Pediatric Orthopaedics 2000, 20:259-263.

32. Smits-Engelsman B, Klerks M, Kirby A: Beighton Score: A Valid Measure for Generalized Hypermobility in Children. J Pediatr 2011, 158:119-23.

33. Van der Giessen LJ, Liekens D, Rutgers KJM, Hartman A, Mulder PGH, Oranje AP: Validation of Beighton score and prevalence of connective tissue signs in 773 Dutch-Caucasian Children. J Rheumatol 2001, 28:2726-30.

34. Hakim AJ, Sahota A: Joint hypermobility and skin elasticity: the hereditary disorders of connective tissue. Clinics in Dermatology 2006, 24:521-533.

35. Marshall JL, Johanson N, Wickiewicz TL, Tischler HM, Koslin BL, Zeno S, Meyers AL: Joint looseness: a function of the person and the joint. Med Sci Sports Exerc 1980, 12(3):189-94.

36. Bulbena A, Duro JC, Porta M, et al: Clinical assessment of hypermobility of joints: assembling criteria. J Rheumatol 1992, 19:115-122.

37. Grahame R, Bird H: British consultant rheumatologists' perceptions about the hypermobility syndrome: a national survey. Rheumatology 2001, 40:559-562.
38. Jansson A, Saartok T, Werner S, Renstrom P: General joint laxity in 1845 Swedish school children of different ages: age-and gender-specific distributions. Acta Paediatr 2004, 9:1202-6.

39. Qvindesland A, Jonsson H: Articular hypermobility in Icelandic 12-years olds. Rheumatology 1999, 38:1014-16.

40. Bird HA, Tribe CR, Bacon PA: Joint hypermobility leading to osteoarthrosis and chondrocalcinosis. Ann Rheum Dis 1978, 37:203-211.

41. McCormack M, Briggs J, Hakim AJ, Grahame R: A study of joint laxity and the impact of the benign hypermobility syndrome in student and professional ballet dancers. Journal of Rheumatology 2004, 31:173-178.

42. Binns M: Joint laxity in idiopathic adolescent scoliosis. J Bone Joint Surg (Br) 1988, 70-B:420-2

43. Weiss HR, Maier-Hennes A: Specific Exercise in the Treatment of Scoliosis - Differential Indication. In The Conservative Scoliosis Treatment. Edited by: Grivas TB. Amsterdam: IOS Press; 2008:173-190.

44. Keer R, Grahame R: Hypermobility Syndrome. Recognition and Management for Physiotherapists. 1 edition. Edinburgh: Butterworth Heineman; 2003.

doi:10.1186/1748-7161-6-22

Cite this article as: Czaprowski et al:: Joint hypermobility in children with idiopathic scoliosis: SOSORT award 2011 winner. Scoliosis 2011 6:22.

\section{Submit your next manuscript to BioMed Central and take full advantage of:}

- Convenient online submission

- Thorough peer review

- No space constraints or color figure charges

- Immediate publication on acceptance

- Inclusion in PubMed, CAS, Scopus and Google Scholar

- Research which is freely available for redistribution

Submit your manuscript at www.biomedcentral.com/submit
C) Biomed Central 